\title{
Byggeri og bygmestre i Åbenrå 1840-1914
}

\author{
Af J. P. la Cour Dragsbo
}

\section{Indledning}

Byggeriet i Sønderjylland i tiden 1864-1920 har indtil nu været et upåagtet kapitel i dansk arkitekturhistorie. Også i det øvrige Danmark har man betragtet denne tids stil som et udtryk for stilforvirring o. lign. Men i Sønderjylland har tidens frembringelser ydermere måttet bære prædikatet tysk, preusserstil osv. Jeg vil senere vise, at dette er delvis urigtigt, idet man dels i selve perioden ikke opfattede nogen stil som værende specielt tysk eller dansk, og dels var der i det almindelige borgerlige byggeri endnu op mod 1900 mange træk, der pegede tilbage på specielt sønderjydske traditioner fra før 1864 .

Selv om byggeriet i Åbenrå på grund af stagnationen efter 1871 var ret beskedent selv $\mathrm{i}$ forhold til de andre sønderjyske byer, er der dog byggeri nok til at følge perioden hele vejen.

I det følgende vil jeg dels følge de forskellige bygmestre, der virkede $\mathrm{i}$ perioden, dels påvise de kulturelle traditioner og forandringer, der lå bag ved byggeriets ydre kendetegn. Endelig vil jeg søge at påvise byggeriets afhængighed af den sociale og okonomiske udvikling, faktorer, der især bestemte byggeriets form, omfang og karakter.

\section{Abenrå 1840-1864}

Fra 1760-70 indtil ca. 1840 var forandringerne i bybilledet minimale, og byggeriet var nærmest gået $\mathrm{i}$ stå. Men fra 1830'erne begyndte det at gå fremad, dels for søfarten, men endnu mere for handel og skibsbyggeri. De forbedrede trafikforhold gjorde sammen med bedre konjunkturer for landbruget, baseret på især korneksport, grad- 


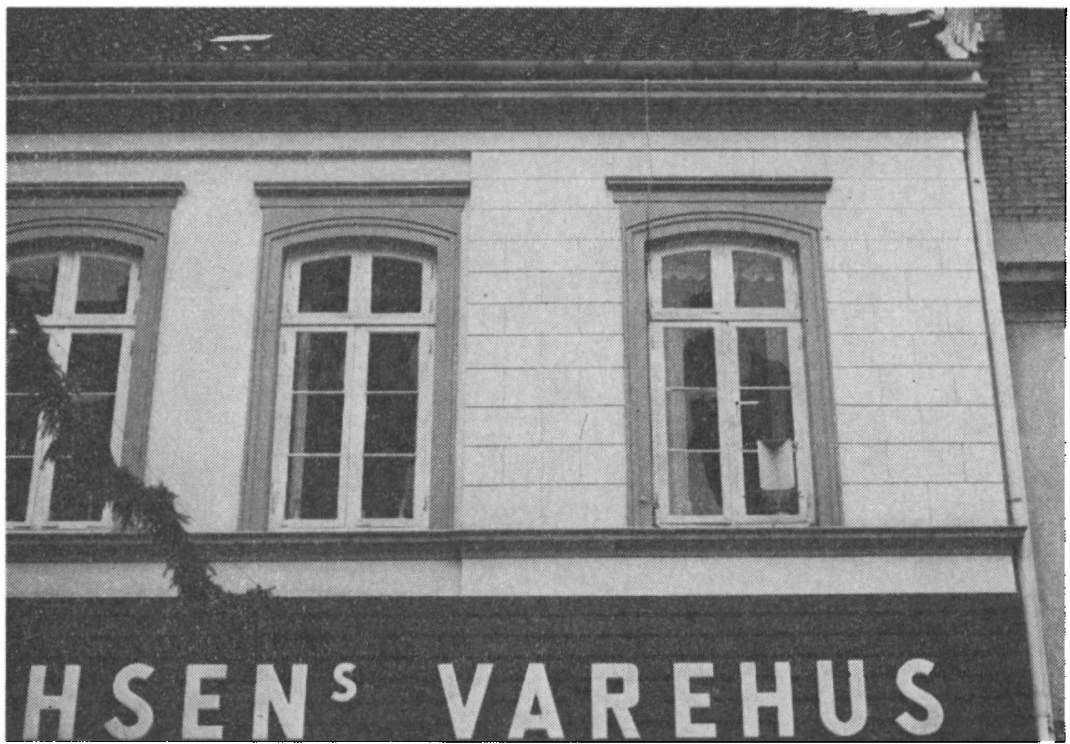

Ramsherred 42, bygget 1852.

vis Åbenrå til en oplandsby, noget den ikke i så høj grad havde været tidligere. Endnu i 1830 var der højt regnet 5-6 egentlige købmænd i byen, men fra 1840 steg deres antal. Og købmændene opretholdt århundredet ud deres stilling som byens øverste og ledende sociale lag.

Det kan derfor ikke undre, at en del af byggeriet 1840-64 var præget af købmændenes nye store huse og pakhuse, de sidste ikke mindst også beregnet til oplagring af skibsproviant. Handelsstrøget var dengang Søndergade, Store Torv og -gade samt Ramsherred.

Det andet blomstrende erhverv var som sagt skibsbyggeriet. Opkomsten af en ny arbejderklasse bevirkede et stort nybyggeri af småhuse, især i kvarteret bag Skibbroen og ved Sønderport. Det var kun i mindre grad udlejningsbyggeri; husene blev for en stor del ejet af beboerne selv. Men omkring 1850 gav presset på boligmarkedet sig dog udslag i, at to af skibsbygmestrene - antagelig med Bruhns Kalø som forbillede - byggede de "lange huse « Tømmergården og Rådhusgade for deres egne arbejdere. Denne form for organiseret arbejderboligbyggeri var ellers ved denne tid et ret ukendt fænomen $\mathrm{i}$ byerne, 


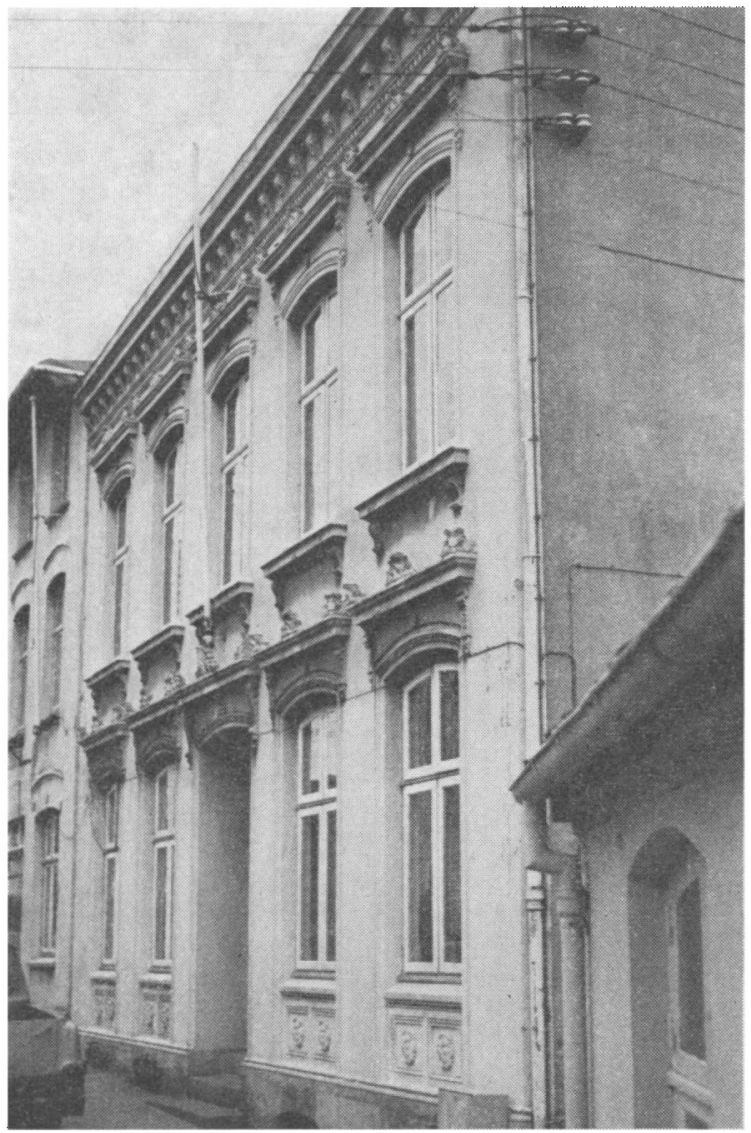

Nygade 12 fra 1866, et af de bedste eksempler på den pyntelige senklassicisme efter 1864 .

men var en gammel tradition ved »land «-industrier: svenske »bruk «, Mølleåfabrikkerne, Kobbermølle $\mathrm{o}$. lign. Til gengxld var arbejderne $\mathrm{i}$ disse huse antagelig mere afhængige af ejeren/arbejdsgiveren. Rådhusgadelængen blev udstykket omkring 1870, mens Tømmergårdens arbejdere fortsatte deres tilknytning til skibsbygger Paulsens virksomhed, også efter at værftet var lukket.

Foruden skibstømrerne byggede også underleverandørerne til skibsbyggeriet huse $\mathrm{i}$ havnekvarteret. Men søfartens kaptajner og styr- 
mænd boede endnu enten $i$ gårde eller huse på Løjtland eller overvejende til leje $\mathrm{i}$ selve byen, og de betød derfor ikke så meget for byggeriet.

Og karakteristisk er det, at $\mathrm{i}$ de traditionelle håndværkergader som Slotsgade, Vestergade og dele af Nygade blev der i denne periode bygget forholdsvis lidt. Derimod var også Vægterpladskvarteret beboet af de småfolk, der fik særlig gavn af det økonomiske opsving.

\section{Byggeri og bygmestre 1840-1864}

Så meget om byggeriets sociale forudsætninger. Ser vi på bygmestrene, der udformede det, er mig i skrivende stund blot tre bekendt: Peter Callesen og henimod 1864 hans søn Johann Heinrich Callesen, samt Carl Langschwager.

Peter Callesen havde i 1835 sammen med C. F. Hansen opført rådhuset, og dette forblev længe normgivende for byggeriet. Især kvaderlisenerne $\mathrm{i}$ hjørnerne og de høje vinduer brugte Callesen senere $i$ mange huse. Men i ovrigt kan disse og andre stiltræk fra rådhuset, ikke mindst hoveddøren, genfindes overalt $\mathrm{i}$ byen, uden at det behøver at tilskrives Callesen.

Til denne »familie« af huse, der bl. a. efter J. H. Callesens notater kan tilskrives P. Callesen, hører Klinkbjerg 2 (1835) og Ramsherred 36 (1848), begge opført for starre købmænd. På det sidste er der en lille firkløverfrise mellem etagerne, som man også genfinder på Richelsens Stiftelse, Nygade 59 (1845-55). Men dette hus kan, ligesom Der Nordschleswigers nedrevne hus på Skibbroen, der også var inspireret af rådhuset, ikke sikkert tilskrives Callesen. Det kan heller ikke de to, ret ens, meget fine huse i senklassicismens manér med kvaderfuget mur og fladbuestik, Fiskergade 9 (1853) og Ramsherred 42 (1852), begge opført for storkøbmænd. Her er stilen mere "nutidig", hentet fra samtidens Hamborg og Kobenhavn. Derimod kan Storetorv $5 \mathrm{i}$ en mere gammeldags klassicisme, med en senere kvist og Søndergade $24 \mathrm{i}$ en enkel stil, med et udsigtstårn, inspireret af italienske villaer, tilskrives Callesen, ligeledes Elisabethsminde, bygmesterens slægts gård, og antagelig også de Bruhnske huse Klinkbjerg 24 og 34 (ca. 1850-60).

Rundt omkring i gaderne står endnu mange huse, der knytter sig til den callesenske stil, f. eks. Skibbrogade 19-21 (1854) og 23 (1847), 


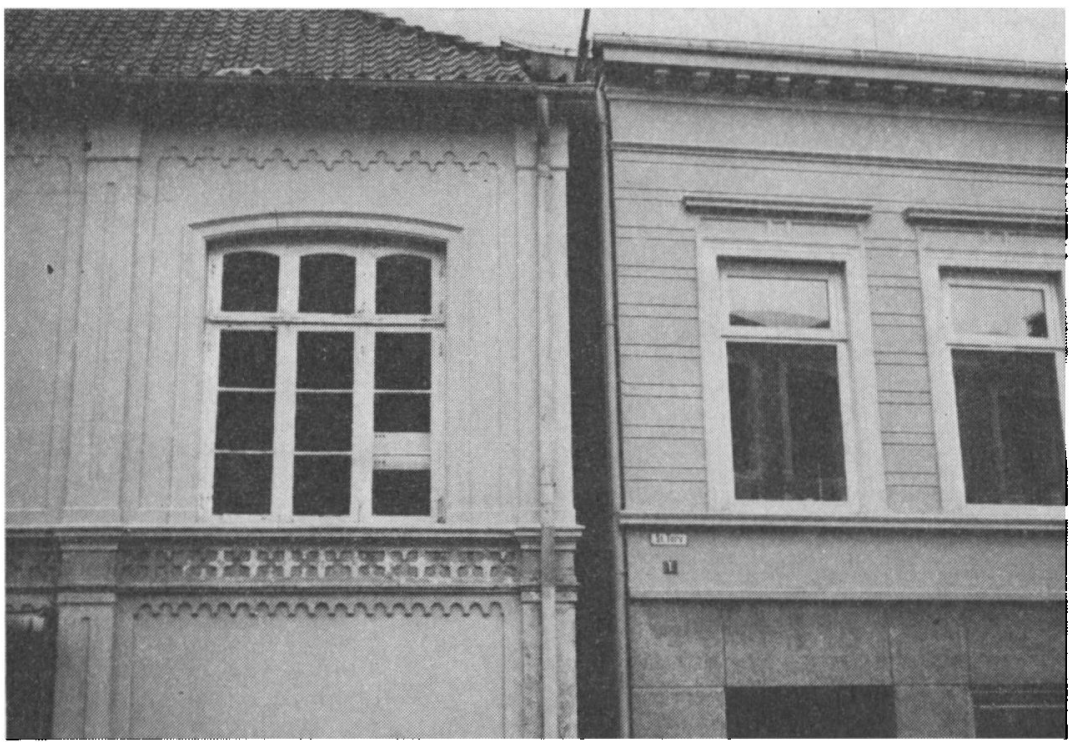

Til venstre Storegade 35 og til bøjre Storetorv 1. Nr. 35 er opfort 1848 af Peter Callesen, nr. 1 er fra ca. 1865-75.

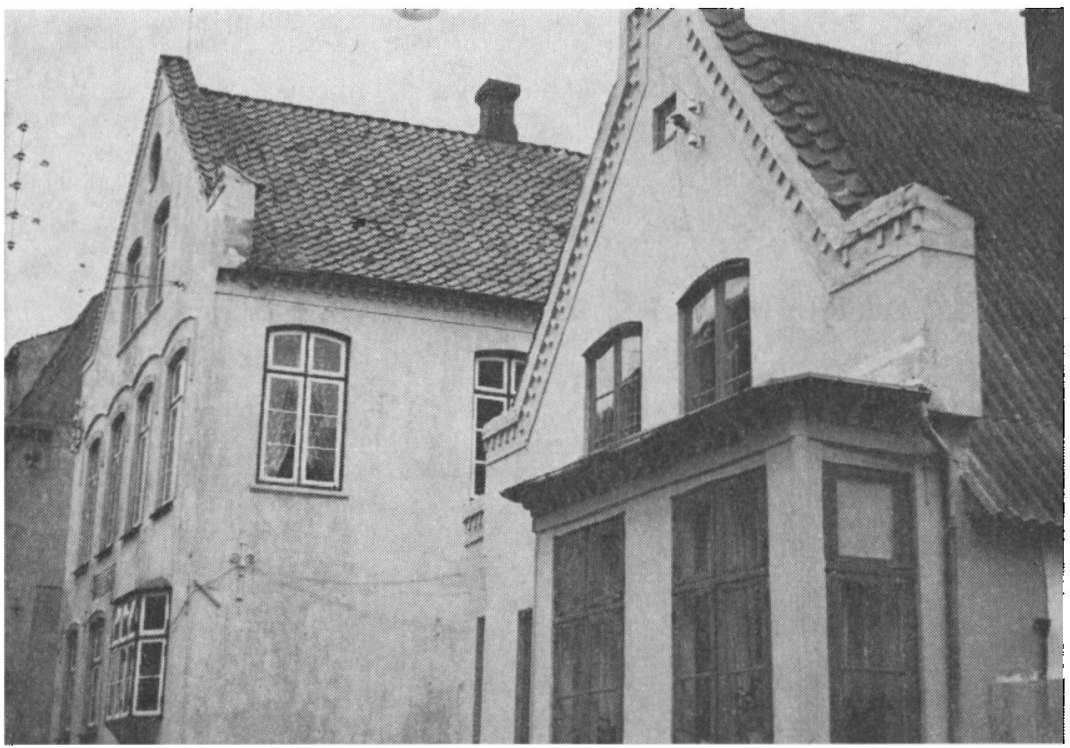

Nygade 45 og 47 med gavle fra tiden 1865-75. Huset til venstre tilhorte bygmestrene Callesen fra ca. 1864 til ca. 1900. 


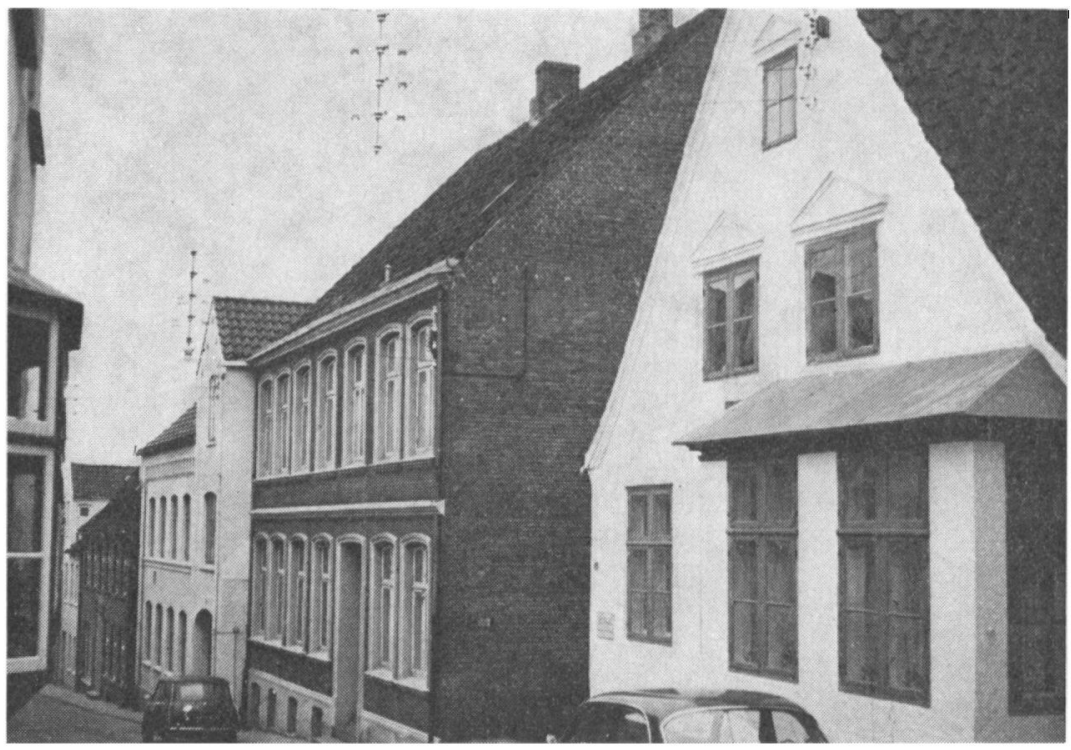

Nygade set mod syd. Til bøjre nr. 50 fra 1748, derefter nr. 52 fra 1898, nr. 54 fra 1865 og nr. 56 fra 1750. Nr. 50 tilhørte bygmestrene Callesen fra ca. 1830 til 1881.

Nygade 48, Günderoths skole (1847), og det pæne hus Storegade 36 (ca. 1860-70).

Af Carl Langschwagers huse kan kun med sikkerhed nævnes »det lange hus « (Tømmergården, ca. 1850), den nedrevne kaserne på Markedspladsen samt Sønderport 65, Bellevue.

Men allerede i slutningen af 1840 'erne viste reaktionen mod C. F. Hansentiden sig $i$ en stigende tendens til frit at anvende motiver fra de historiske stilarter. Peter Callesen gik vel selv i spidsen så tidligt som i 1848, da han byggede Storegade 35, den gamle biograf, i en let og enkel nygotik. Men først da landbygmester Winstrup opførte Günderoths stiftelse 1860 og pigeskolen Nygade 55 1858-62 i henholdsvis nyrenaissance og nygotik med trappekvistgavl, holdt den nye tid sit indtog.

\section{Abenrå 1864-1890}

Efter 1864 kom der en kort periode med stor fremgang og aktivitet, 


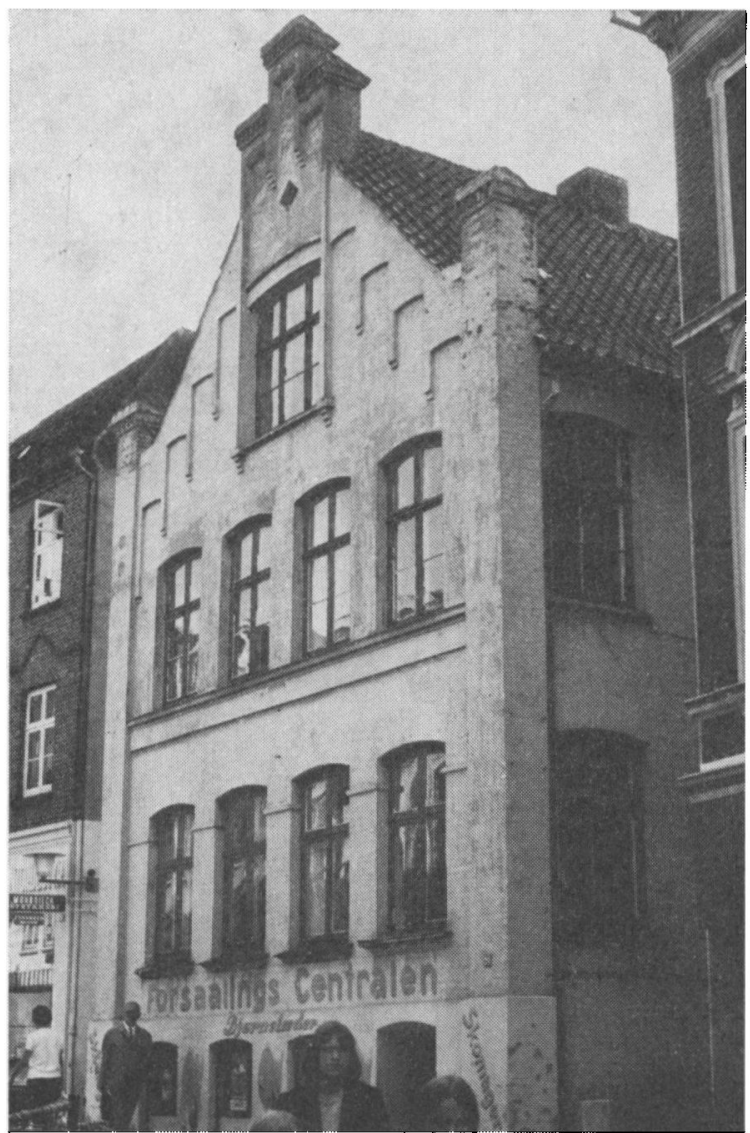

Ramsherred 20, bygget 1870. Et godt eksempel pa nygotikken efter 1864, nu nedrevet.

antagelig båret af den nu tyskorienterede overklasses forhåbninger til fremtiden. Rådhusgade anlagdes efter flensborgsk forbillede 1868-69, og de sidste grunde ved den gamle bydels gader bebyggedes. Men efter 1871 blev de første udvandringsbølger mærkbare, landsdelen mistede både indbyggere og kapital. Samtidig nåede det store "Gründerkrak « Ảbenrå i slutningen af halvfjerdserne, og ydermere standsede skibsbyggeriet, ikke gradvis, men i løbet af de to år 1878 og 1879. I årene derefter beretter rapporter fra byen om en stærk udvandring og særdeles ringe byggevirksomhed. Allerede 1870 havde 


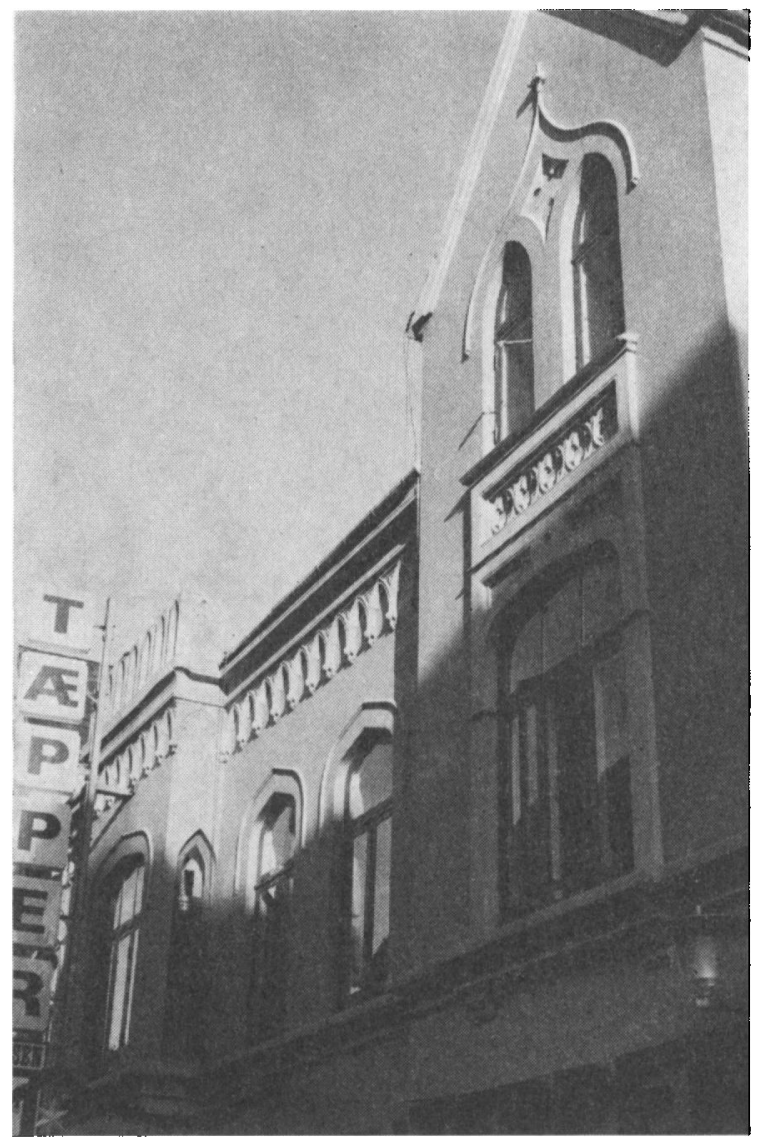

Ramsherred 51. Opfart 1874 af J. H. Callesen for kabmand Jürgen Lorenzen.

ưvandringsagenter slået sig ned $\mathrm{i}$ byen, og målet var især Amerika, især efterhånden som det var økonomiske mere end nationale grunde, der drev folk bort.

I begyndelsen af 1880'erne forsegte skibsbygger Paulsen sig med et savværk, et andet skibsværft fortsatte med reparationer, og endelig oprettedes Bastiansens maskinfabrik og Overbecks kalkbrænderi først på Nørre Chaussée. Men det var langtfra nok til at erstatte det enorme fald i arbejdspladser; en hel part af byens liv var blevet skåret væk. 
Men en by er en så sammensat række af funktioner og aktivitetsfelter, at der ikke behøver at være direkte afhængighed mellem alle de $\mathrm{i}$ byen boende befolkningsgrupper. Så mens nød og elendighed herskede i Gildegade og Sønderport, hvor skibstømrerne boede, og f. eks. i Slotsgade og Skibbrogade, hvor underleverandørerne boede, fortsatte købmandsstanden sin befæstning af Ảbenrå som oplandsby. Og langs hovedstrøget var byggeaktiviteten hos købmænd og handlende da også lige så stor $\mathrm{i}$ denne som $\mathrm{i}$ den foregående periode.

Endvidere skete der det efter 1870, at søfarten langsomt formindskede sin tilknytning til Løjtland. Kaptajnerne valgte nu at bygge deres villaer nær byen, især langs Nørre Chaussée (Haderslevvej), begyndende med "Chinatown « fra 1874-75. Netop her har vi et godt eksempel på, hvorledes villabegrebet har sin rod i 1800-tallets landstedstradition. Der er en jævn overgang fra landstedet (f. eks. i Stentoft) til byvillaen op mod 1900.

Byggeriet $\mathrm{i}$ hele byen prægedes også af, at det næsten udelukkende var købmænd og kaptajner, der byggede. Det var store huse med en fremskreden boligkultur. Samtidig blev Ábenrås nye kvarterer villakvarterer $i$ en grad, der er sjxlden for købstæder, men som kan sammenlignes med søfartsbyer som Svendborg og Helsingør og "pensionistbyer « som Fredensborg.

\section{Byggeri og bygmestre 1864-1890}

Ser vi på bygmestrene, er det først Johann Heinrich Callesen, der præger billedet. Efter 1880 overtager hans søn Peter Callesen det meste byggeri. Af Langschwager-slxgten er det Wilhelm Langschwager, der bygger, og endelig er der en murermester Robert $\mathrm{H}$. Luppi.

Der var så at sige tre stilretninger $\mathrm{i}$ det tyske Nordslesvig på denne tid. Der var den af Winstrup inspirerede nygotik: trappegavle, karnapper og kviste, dog altid udført med en vis enkelhed og beherskelse.

Det var forst og fremmest J. H. Callesen, der byggede sådan, $f$. eks. i Nygade 54 (1865), Kirkepladsen 5 (senere ombygget), Nygade 41 (1868-70 for dr. Grauer, senere H. P. Hanssens hus), og først og fremmest Ramsherred 51, som han 1874 byggede for senator og storkøbmand Jürgen Lorenzen, byens rigeste mand. Det er et af de 


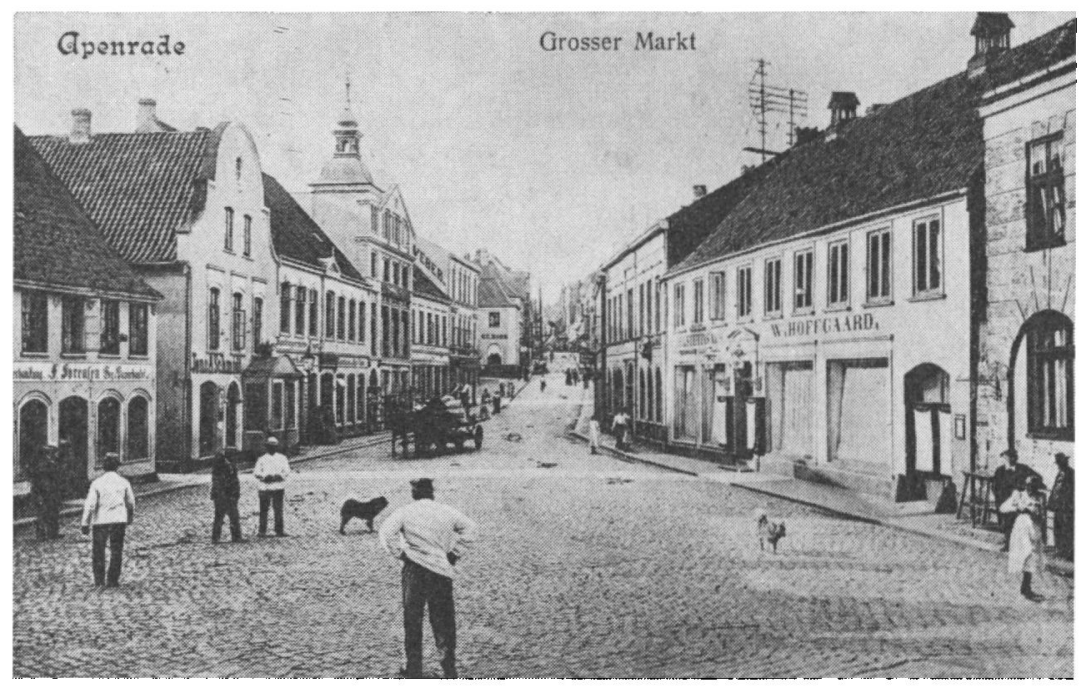

Storetorv. (Postkort i Historiske Samlinger for Sønderjylland)

mest storslåede borgerhuse, der nogensinde er blevet opført i byen, et af de få vidnesbyrd om Gründertidens forbigående opsving. Endvidere har J. H. Callesen med sikkerhed bygget Ārupgård (1872) syd for byen og avlsbygninger flere andre steder. Til denne provinsielle gotik knytter sig huse som Haderslevvej 48-50 (1874-75), Nybro 8 (ca. 1870), Ramsherred 20 (ca. 1875, nedrevet) samt adskillige gavlhuse, der fik små tinder og takker. Det er $\mathrm{i}$ øvrigt interessant, at gavlhuset $\mathrm{i}$ Sønderjylland fik en renaissance ved denne tid, det var antagelig velegnet til "romantiske udformninger. Om denne gotiske interesse havde noget at gøre med det nye nationale tilhørsforhold, er et spørgsmål, $i$ hvert fald finder vi den ret så sjxldent nord for den gamle grænse.

Til gengæld brugtes den af italienske forbilleder prægede efterklassicisme flittigt i Danmark, men næsten ikke i Sønderjylland. I Åbenrå finder vi huse som Løveapoteket, Storetorv 1 (ca. 1870-75), Nørreport 20 (1865), Storegade 38 (ca. 1865-70, - et fantastisk hus, tårnet er dog fra 90'erne) samt Klinkbjerg 7 fra 1880 med nogle her i byen sjxldne rundbuede vinduer. For sig selv står $f$. eks. den svungne gavl på Storetorv 4 (1869), og især et hus som Nyvej 3 
(1866) med sin overdådige italiensk-byzantinske teglstensornamentik. Bygmesteren er ukendt, men J. H. Callesen er da mulig.

Den stil, der skulle blive hængende $\mathrm{i}$ byen indtil 1890'ernes begyndelse, var imidlertid en pyntelig senklassicisme, som stod $i$ fuldt flor $i$ Nordeuropa i 1850'erne f. eks. i Hamborg, Berlin og København, men som senere blev næsten en slags slesvigsk lokalstil. Den prægede især Sønderborgs genopbygning efter 1864 og udmærker sig især ved pudsede, lyse facader med store, fladbuede vinduer, hvorom indfatninger og fordakninger med pynt og palmetter lejrer sig. I det hele en enkel og renfærdig stil, egentlig blot en videreudvikling af den gamle Peter Callesens stil.

Vi møder disse huse bl. a. i Skibbrogade 17, et ældre hus med facade fra ca. 1870, men mest fornemt $i$ de to næsten ens huse Nygade 12 (1866) og Ramsherred 7 (1875). Ydermere står begge huse næsten fuldstændigt som ved opførelsen uden skæmmende skiltning eller "moderne« ruder. De fortjener absolut opmærksomhed! Nygade 12 tilskrives ret usikkert J. H. Callesen, men helt sikkert har han bygget Søndergade 19 (1875) og Vestergade 17. (1872) med de buede ruder.

Der sker så godt som ingen forandringer fra 1870 til 1890. De samme detailler breder sig over facaderne, som var de lavet på ét og samme værksted. Det gælder som førnævnt adskillige huse på hovedgaden, f. eks. Storetorv 2 (1877), Nørretorv 1 og 2, xldre huse, og, som tegn på at byens tyngdepunkt nu flyttede nord på, en hel husrække i Nørreport fra midten af 1880'erne, hvor vi for første gang møder Wilhelm Langschwager som mester for $\mathrm{nr}$. 18 (1882). Og endelig er der en række af kaptajnsvillaerne på Haderslevvej (f. eks. nr. $2,15,37,41,46)$.

At stilen godt kunne kombineres med den romantiske brug af kviste og støbejernsaltaner, kan man se allerede i Storegade 6 (1865) med byens xldste butiksvinduer og i Nygade 63 (1873). Men flottest dog i Ramsherred 37-39, der byggedes 1880 , efter al sandsynlighed af Peter Callesen den yngre. Han havde en forkxrlighed eller en skabelon på værkstedet? - for store bueslag over vinduerne; han brugte dem i hvert fald meget smukt på Nørreport 30, bygget 1886 for kornhandler Ries.

$\mathrm{Ja}$, alle disse huse var bygget for storkøbmænd, og bygherrens status kan ikke blot læses af husenes størrelse, men også af mængden 
J. P. LA COUR DRAGSBO

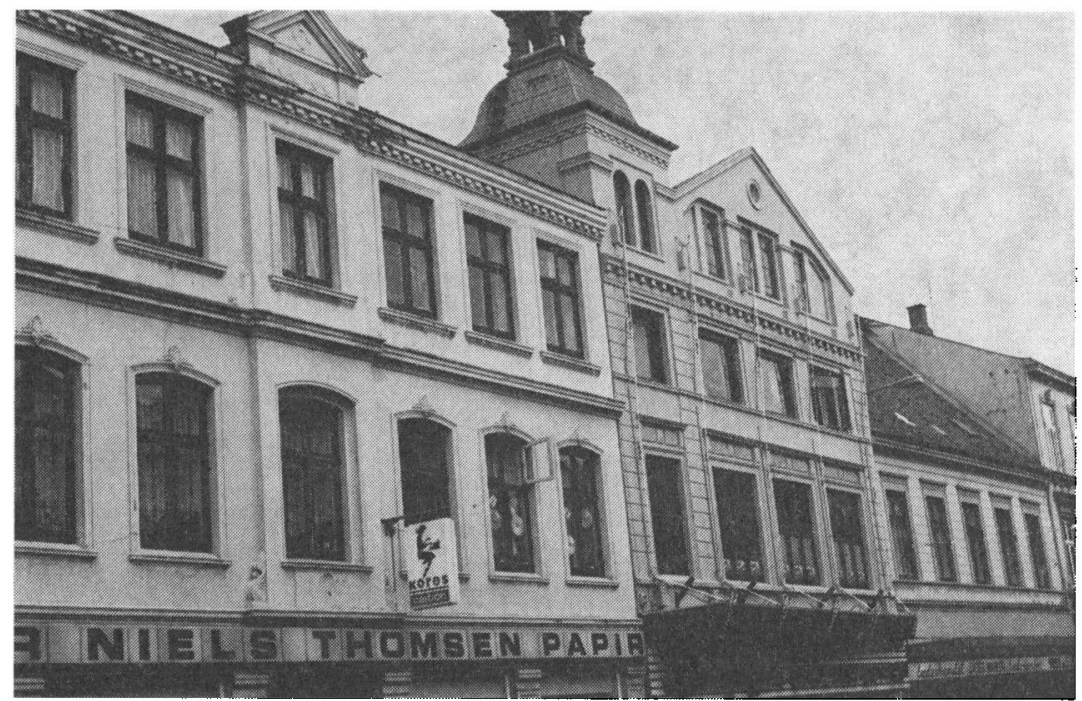

Storetorv 2 og Storetorv 38. Nr. 2 fra 1877 og 1884, nr. 38 fra 1860'erne med tån fra 1898.

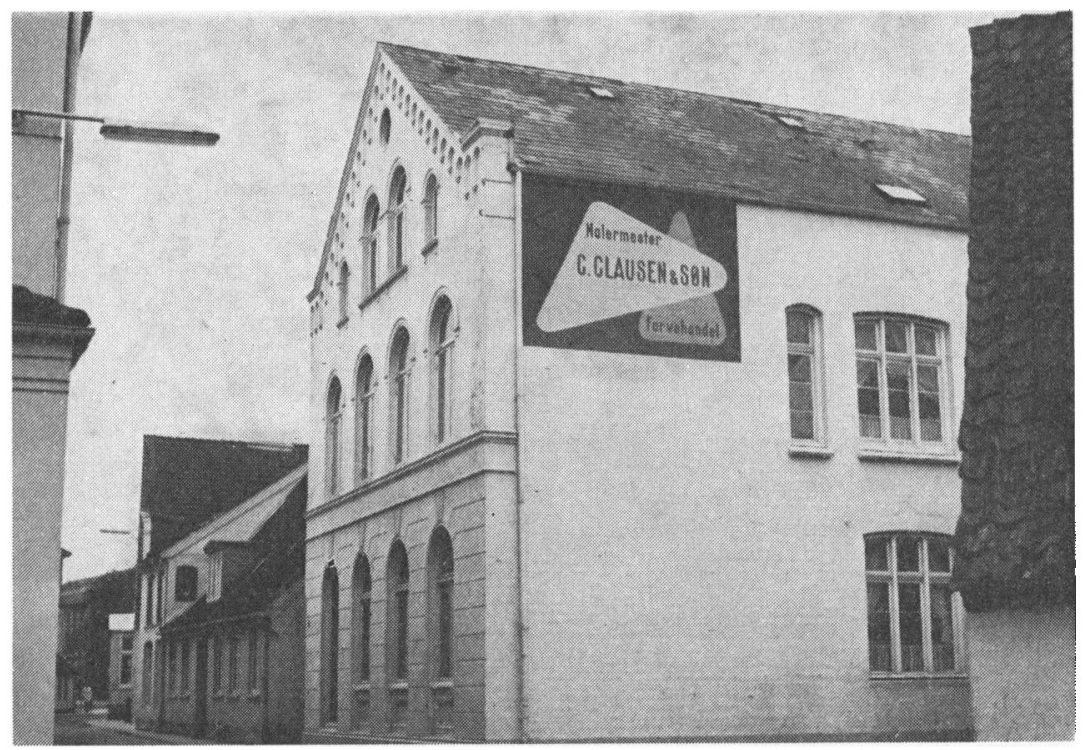

Klinkbjerg 7, opført 1880. 
af dekoration, der skulle demonstrere ikke blot god okonomi, men også god smag. Og ser man efter, er Peter Callesen ikke sluppet helt dårligt fra tegnebordet!

\section{Abenrå 1890-1905}

Fra midten af $1890^{\prime}$ erne kom der igen gang i byens udvikling. Dette skyldtes tildels en svagt voksende industrialisering, men endnu mere en kraftig ekspansion $i$ den offentlige administration. Til kaptajnernes villaer føjede sig nu embedsmændenes, og denne nye gruppe voksede helt til 1914. Samtidig voksede der en middelklasse op, bestående af funktionærer, mindre kaptajner og pensionister, rentier'er, og de efterspurgte en ny boligform: lejligheden.

Hidtil havde det højere og lavere borgerskab boet $i$ egne huse, de handlende over butikken med slægtninge og enker som logerende, der tit indgik $\mathrm{i}$ husstanden, og håndværkerne $\mathrm{i}$ tilknytning til arbejdet. Håndværkerne havde deres mindre huse $\mathrm{i}$ den gamle bydel med

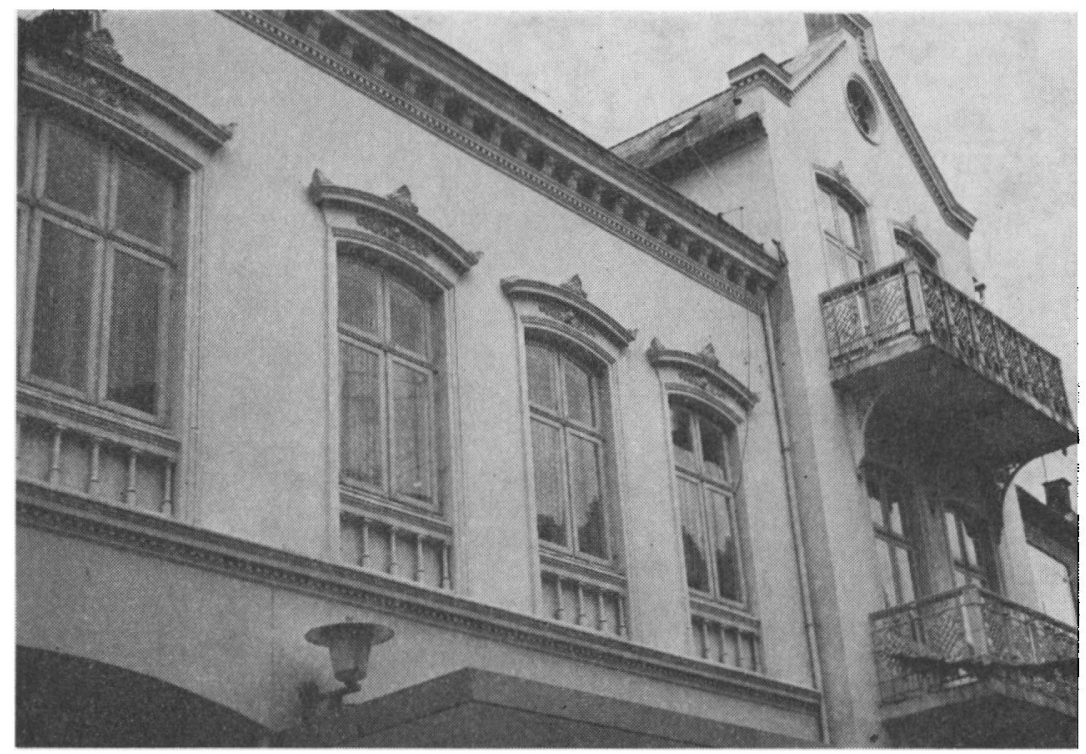

Ramsherred 39, opfort 1880 antagelig af Peter Callesen d. yngre for købmand Voetmann. 


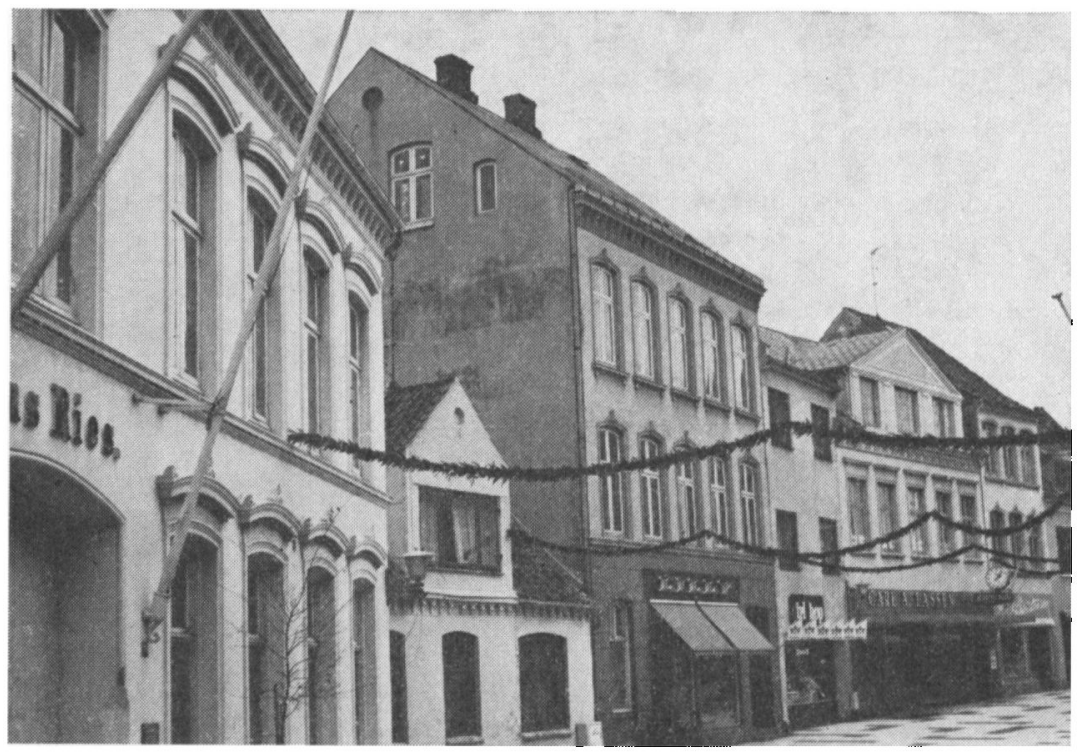

Norreport set mod nord. Til venstre nr. 30, opfort 1886 af Peter Callesen d. yngre for kornhandler Ries.Nr. 28 fra 1887 og nr. 26 opført 1882 af Wilbelm Langschwager. Nr. 22 fra 1865 og senere og $\mathrm{nr} .20$ fra 1882.

baghuse og kviste udlejet til enlige og daglejere, samtidig med at svende og læredrenge indgik $\mathrm{i}$ håndværkerens eget hushold.

$\mathrm{Nu}$ blev der et marked for udlejningsejendomme for middelstanden. Allerede i 1894 byggede Peter Callesen det nu nedrevne Friedensheim, Haderslevvej 11 ved Folkehjem, og 1898-1900 lod en grundejer K. Detlefsen, Kolstrup, de store huse Haderslevvej 20-22 bygge med ialt en halv snes lejligheder. Samtidig påbegyndte Peter Callesen det største byggeri i byen på den tid: anlægget af Callesensgade med de tårnprydede hjørnehuse mod Forstallé. Ialt byggede han her i tiden 1898-1905 ca. 25 3-5 værelseslejligheder for borgerskabet.

Folketællinger og huslejelister viser, hvem der flyttede ind. Det var først og fremmest embedsmænd og pensionister samt nogle enker og kaptajner. Huslejen lå på 200-600 mark om året mod 50-100 mark i arbejderkvartererne og enkelte på over 1000 mark på hovedgaden. Ja, der var endelig begyndt at strømme arbejdere til Ảbenrå, dels 
fra oplandet og dels sydfra. Dermed opstod der boligmangel og huslejeproblemer som $\mathrm{i}$ vore dage. Også her var Peter Callesen forst $\mathrm{i}$ marken. År 1900 gik han igang med de første privatbyggede "Arbeiterwohnungen « $i$ byen. Det blev små spartanske huse, bygget på kanten af byggeloven, eller $\mathrm{i}$ hvert fald efter megen diskussion med bygningsmyndighederne, ikke ved den nye fornemme gade, men ved en ekstra lille baggade, Feldstrasse, nu Lavgade.

Her blev huslejerne 100-200 mark årligt, så det blev ikke den fattigste del af arbejderbefolkningen, der flyttede ind. Det blev ikke mindst jernbane-, post- og kommunalfunktionærer; dertil kom nogle enker, men ret generelt var det børnerige familier, der kom til at bo $\mathrm{i}$ husene. $\mathrm{Nu}$ besluttede kommunen sig imidlertid til selv at bygge arbejderboliger. I 1904 byggedes de forste 4 i Feldstrasse/Lavgade efter ideer bl. a. fra Heide og Frederiksstad. Som en mindelse om den tids tilskud til småfolks husholdninger horte der til hvert hus en lille have og en svinesti. Senere byggedes dog også kommunale arbejderboliger i fleretages huse. Peter Callesens projekter standsede ved hans død 1905, men næste generation, arkitekterne Ingwart og Peter Callesen

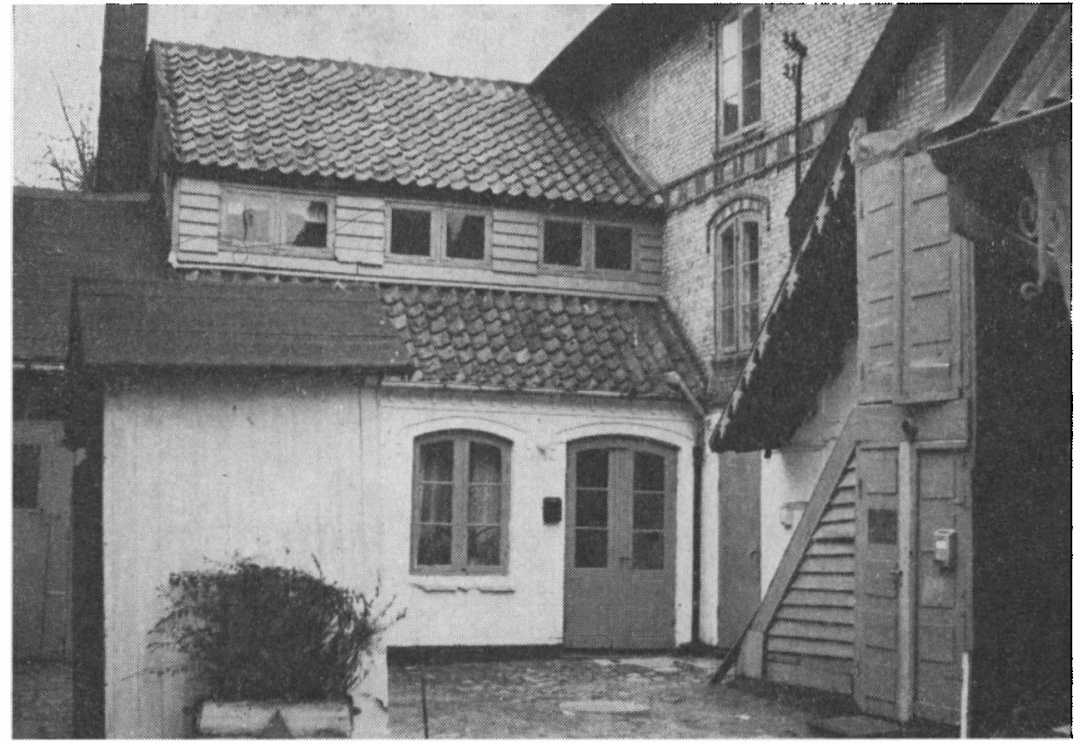

Nygade 47, baghusene $i$ gården. Om- og tilbygninger fra tiden omkring 1890. 


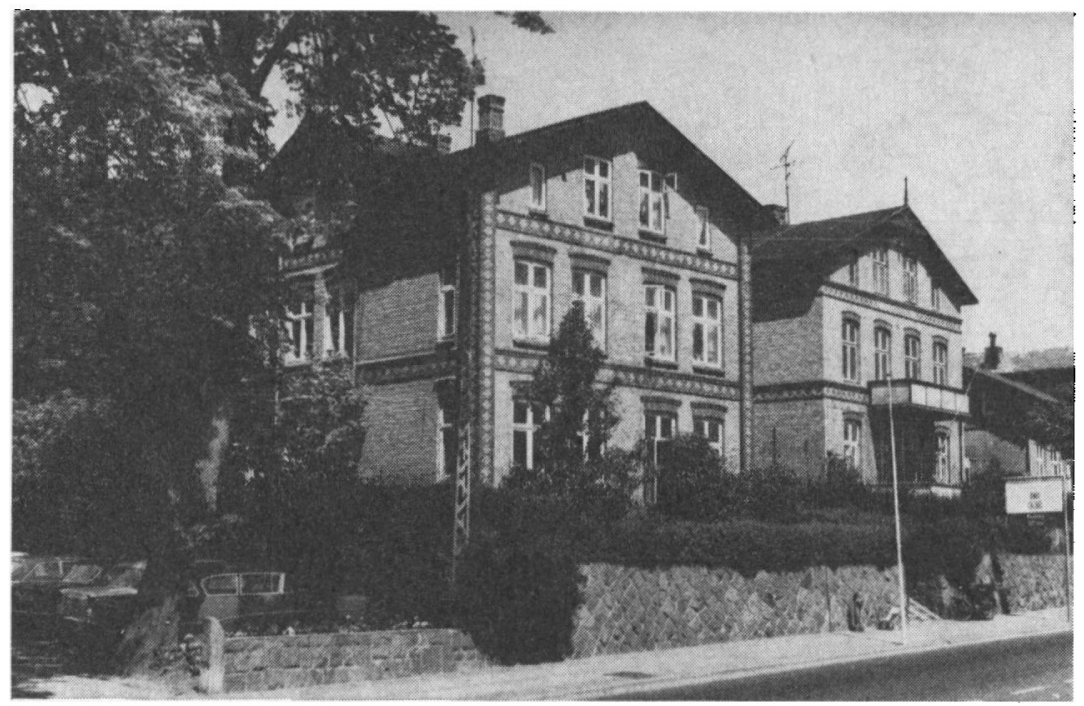

Haderslevvej 9-11, nu nedrevet. Nr. 9 er bygget 1896 af $N$. Lorenzen, nr. 111894 af og for Peter Callesen.

fortsatte byggeriet af udlejningsejendomme ved Møllegade og Tværgade.

Ellers byggedes der kun større udlejningsejendomme først på Forstalle og på et stykke af Karpedam. Det overvejende byggeri var imidlertid, indtil 1920, villaerne for de borgerlige klasser.

Selve den gamle bydel undergik også forandringer, ikke blot $\mathrm{i}$ udseende, men også i social struktur. Disse forandringer skete nogenlunde parallelt med de fleste andre større og mindre købstæder $\mathrm{i}$ Danmark, Nordtyskland og Skåne i industrialiseringens tid. De største forandringer skete med håndværkerklassens kvarterer. F. eks. blev gader som Slotsgade og Nygade nu befolket af arbejdere og lignende befolkningsgrupper. Husene blev opdelt i flere og flere lejligheder, en proces, der op imod vore dage kan betyde en fare for »forslumning «. Omvendt blev de tidligere småfolkskvarterer som Pottergade og Gildegade også kvarterer for arbejderklassen, hvilket ikke her betød nogen social nedgang, snarere tværtimod. Endvidere delte håndværksfagene sig groft sagt $\mathrm{i}$ de håndværk, der udviklede sig til butikshandel (især i Vestergade og på hovedgaden), de hånd- 
værk, der overgik til reparation (i baggårdene) og de, der udviklede sig til industriel produktion som $\mathrm{f}$. eks. Tonderings læderfabrik i Nygade, der fra ét garveri med 2 ansatte i 1870-80 udviklede sig til en fabrik med 50-100 ansatte i 1900-10.

Typisk for håndværkerkvartererne var f. eks. også, at svendene, der for boede hos mestrene, efter 1890 i stigende grad dannede egne husstande. Det samme skete med de ansatte hos købmændene. De reducerede husstande hos købmænd og håndværkere betød dels, at disse ikke mere behøvede at bo i tilknytning til arbejdet, dels, at der frigjordes plads til lejligheder og værelser for logerende ikke mindst langs hovedgaden. En mængde om- og tilbygninger skete overalt i den gamle bydel, mens nybyggeriet her mest bestod af butiks- og beboelsesejendomme på hovedgaden. Der var stadig købmænd, der byggede nyt; men det var som følge af handelens specialisering, nu ikke mindst andre handlende, og derudover folk som advokater, læger og enkelte kaptajner, der byggede og boede på hovedstrøgene. Endvidere byggedes der enkelte fabrikker og ved kirken en rakke stiftelser.

\section{Abenrå 1905-1914}

I tiden 1905-14 fortsatte den udvikling, som var begyndt i 1890'erne. I stadig større grad adskiltes bolig og arbejdssted. Hvor købmændene før havde varetaget en stor del af handelen, rettede de sig nu især mod engrosvirksomhed og fabrikation. Ja, flere firmaer blev aktieselskaber eller overtoges af større tyske firmaer. Samtidig blev byens butiksmønster stadig mere varieret, og endnu flere håndværkere overgik til butiksdrift. Specielt i perioden 1905-14 prægedes byggeriet på hovedgaden af flere nye banker og sparekasser, endnu et tegn på dels den stigende adskillelse mellem de kommercielle funktioner, dels de stadig flere roller, byen kom til at spille for oplandet, selv om de nye stationsbyer nu overtog mange lokale funktioner. Derimod voksede industrien ikke så hurtigt som omkring 1900, og behovet for arbejderboliger var derfor umiddelbart inden 1914 ret lille. Til gengæld byggedes der især nord for byen store mængder af villaer, og dermed flyttede også byens tyngdepunkt nordpå. F. eks. var det meste af Nørretorv indtil ca. 1900 et småfolkskvarter, mere præget af gæstgiverier end af butikker. 


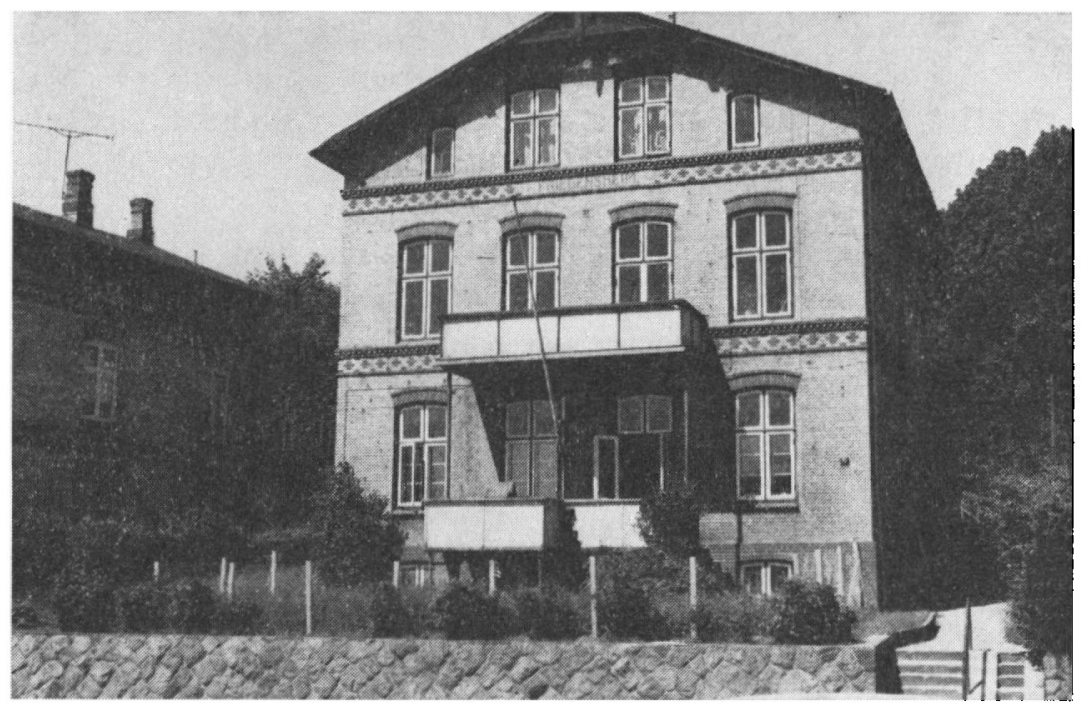

Haderslevvej 11 Friedensheim*, et skoleeksempel påtyrolerstilen.

\section{Byggeri og bygmestre 1890-1900}

Efter 1890 blev antallet af bygmestre og murermestre storre. Der var som sagt Peter Callesen den yngre, der var Wilhelm Langschwager og dennes brodersen Ottomar Langschwager, der var Robert Luppi, C. Iversen, A. Klemz, Flindt, Jes Damm Sørensen, der ansatte en "rigtig" arkitekt, Wehner, D. Dethlefsen, M. B. Matthiessen samt enkelte bygmestre fra andre byer. Henimod 1914 kom så bygmestrene Jep Fink, Viereck og Carstensen til.

Og ser vi på husene, sker der en forandring. Allerede i slutningen af $1880^{\prime}$ erne var der blevet bygget enkelte villaer, der brod noget med de hidtidige traditioner ved ikke at være pudsede, men stod i gule mursten med røde skifter. Endvidere var tagrejsningen blivet lavere, tagudhængene var større og hele husets form kunne nu være mere fri. Man fik en forkærlighed for assymetriske kviste, og af detaillerne kan nævnes kunstfærdige buestik og gesimser $\mathrm{i}$ teglsten.

Den nye stil var en blanding af påvirkninger fra nordtysk teglstensgotik og den tyrolerstil, der også nord for grænsen blev så yndet netop til villaer. Og i Ảbenrå blev den efter 1890 enerådende både i huse og villaer. Selve tyrolerstilens fremhævelse af gavlen som 


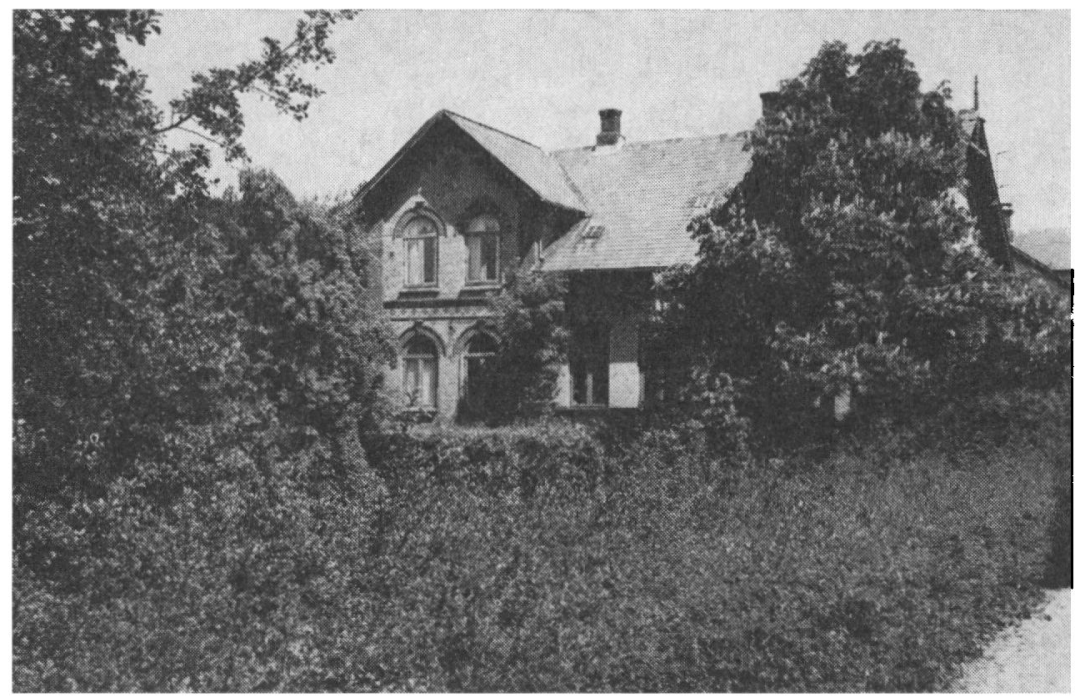

Haderslevvej 23, bygget 1896 af C. Iversen.

facade gik udmærket $\mathrm{i}$ spænd med de hidtidige byggetraditioner i Sønderjylland. Men den lave tagrejsning og den dertil hørende høje trempel var tillige karakteristisk for en husform, der siden 1840-50 havde domineret det meste af Mellem- og Østeuropa, men som forblev så godt som ubrugt i Danmark.

I Åbenrå er der så relativt mange af disse huse, at de flere steder danner en helhed. De store enkle og gedigne, men af og til lidt klodsede huse finder vi især langs Haderslevvej og Forstallé. Især på Haderslevvej lå de indtil et par år siden $\mathrm{i}$ en ubrudt rakke helt ud til Landsarkivet.

Indtil ca. 1900 var Peter Callesen og Carl Iversen næsten ene om at udføre byggeriet, is $x$ r den sidstnæevnte var flittig. De byggede for nogenlunde de samme sociale grupper. Dog var Callesen kendt som dansksindet, hvad der nok har bestemt kundekredsen $i$ en vis grad. Samtidig byggede Callesen i hele perioden fra 1880 til 1905 tit for medlemmer af byens øverste sociale lag. Hertil hører ikke mindst det nedrevne Haderslevvej 3 (1901), der måtte regnes for hans pragtstykke, bygget for en hovedrig kaptajn Schütt.

Callesen gjorde som bygmester rigt brug af glaserede gule sten som 
mønster i mørkerøde mure, og det blev hans specialitet. Dette ses ikke mindst $\mathrm{i}$ de store udlejningsejendomme $\mathrm{i}$ den vestlige del af byen, såsom Forstallé 1 (1899), Nygade 51 (1900) og Callesensgade 27-31 (1901-1905) og 32 (1900). Sammen med en flittig brug af tårne og spir viste Callesen, hvorledes den lokale udformning af den nordtyske stil kunne udnyttes både festligt og farverigt. ${ }^{1}$ De to hjørnebygninger Forstallé-Callesensgade er en af de bedste bygningshelheder, vi her $i$ Sønderjylland har tilbage fra denne tid. Man må derfor håbe, at de må blive bevaret for eftertiden; en eventuel udvidelse af Callesensgade må her kunne klares med en buegang.

Iversen holdt sig til den traditionelle stil til efter 1900. Især på Nørre Chaussée var han flittig; han er mesteren for Haderslevvej 20 (1898), 22 (1900), 23 (1896), 25 (1901), 27 (1900) og 36 (1903), alle huse påfaldende ens udført $\mathrm{i}$ røde og gule mursten. Endvidere har han bygget Forstallé 17 (1902), Lindsnakkevej 91 (1899) og Bjerggade 7-11 (1902), og han færdiggjorde Forstallé 1 i 1900. Også Forstallé 4 skulle have været bygget af Callesen; men det blev murermester A. Klemz, der byggede huset 1901, i øvrigt med mødesal for Indre Mission. Derudover skyldes Møllegade 5 (1899) og Frydendal 5 (1900) Klemz.

J. D. Sørensen fik hurtigt en stor byggeforretning. I starten omkring 1900 byggede han f. eks. Forstalle 3 og 23; men ellers var det mest $\mathrm{i}$ tiden efter 1905, han fik meget at lave. Også Ottomar Langschwager lagde ud ved denne tid med et så nydeligt hus som Forstallé 21 (1900 for borgmester Rickmers). Og for den hovedrige købmand Clausen byggede han Vestergade 8 (1900), et usædvanligt privatpalæ, som stadig er i familiens eje. Stilen er ret traditionel med mindelser om P. Callesens huse fra 1880'erne og forsynet med de dekorative tårne af zink, som Langschwager f. eks. også satte på Storetorv 38 i 1898.

I den gamle bydel skete som førnæunt mange om- og tilbygninger, værksteder, halvtage og kviste i mærkelige former og faconer, sådan som det kan ses i gården til Nygade 47 med det helt grotesk forbyggede baghus. Ellers var nybyggeriet i modsxtning til i de nye kvarterer ikke større end $i$ foregående perioder, og endvidere var det huse af ret forskellig slags. I den traditionelle stil byggedes $f$. eks. Gildegade 18 i 1894 af Robert Luppi for hotelejer Butzbach, og nabohuset Skibbrogade 9 i 1899 af Peter Callesen for kaptajn Gontard. 
Huse af et noget andet præg er Nybro 10 (ca. 1890-1900) med rig brug af formsten og dr. Dibberns mægtige hus, Skibbrogade 7 (1900) opfort af en murermester M. B. Matthiessen $i$ en mere tyskpraget og stilren teglstensgotik. Her er den lokale tradition trådt helt $i$ baggrunden. Men ellers er århundredskiftets huse $i$ den indre by næsten alle skåret over samme læst: langhuse $i$ to etager, røde eller gule teglsten, store buestik over vinduer og døre og eventuelt en kreneleret kvist eller gavl. Stiftelserne på Kirkepladsen ved Lille Pottergade udgør $\mathrm{i}$ denne henseende en typisk helhed. At ældre traditioner ikke var glemte, viser to huse, nemlig dr. Jep Wildfangs hus, Søndergade 7 (1890 af P. Callesen), der blev udført som en tro kopi af Ramsherred 51, Lorenzens hus fra 1874. Og det andet hus er det hus, bygmestrene Wittfoth \& Christensen opførte 1898 for postassistent Karottki i Nygade 52. Det er i en så enkel og gammeldags stil, at man umiddelbart ville tro, at huset var fra 1840'erne.

Mere pyntelige huse, præget af stuk i renaissanceformer, er $f$. eks. Nørreport 6 (1899) og 8 (1900, Iversen) samt Ramsherred 5 (1903, Iversen), 18 (ca. 1900) og 43 (1900, Iversen).

\section{Byggeri og bygmestre 1901-1914}

Men nye tider havde allerede meldt sig. I årene 1891-1907 udførtes en rxkke store offentlige byggearbejder for den preussiske stat: Først sygehuset, så Amtsbanegården, og efter 1900 Amtshuset, Statsskolen, skolen bag Rådhuset og til sidst Tinghuset. Tegningerne blev udført af statslige arkitekter, en arkitekt Angelroth tegnede sygehuset og Jablonowski i Haderslev tegnede resten; men selve byggearbejdet blev udført af Ảbenrå-bygmesteren Ottomar Langschwager.

Dette skyldtes bl. a. ogsă, at han var kendt som værende tysksindet, og straks efter 1900 fik han da også en omfattende byggevirksomhed for de mange nye embedsmænd. Også den flittige Iversen fik mange huse at bygge; men flest byggede J. D. Sørensen, der nu lod en arkitekt B. Wehner tegne husene, og en ny bygmester D. Dethlefsen.

I det nye byggeri slog i løbet af få år en ny, mere officielt præget, tysk nationalromantik igennem, kendetegnet ved en udstrakt brug af karnapper og kviste, store og små tagflader med stejl rejsning, udhæng og valme. Endvidere skiftede tagbeklædningen, der siden 187080 havde haft skifer eller tjærepap som fremherskende materialer, til 


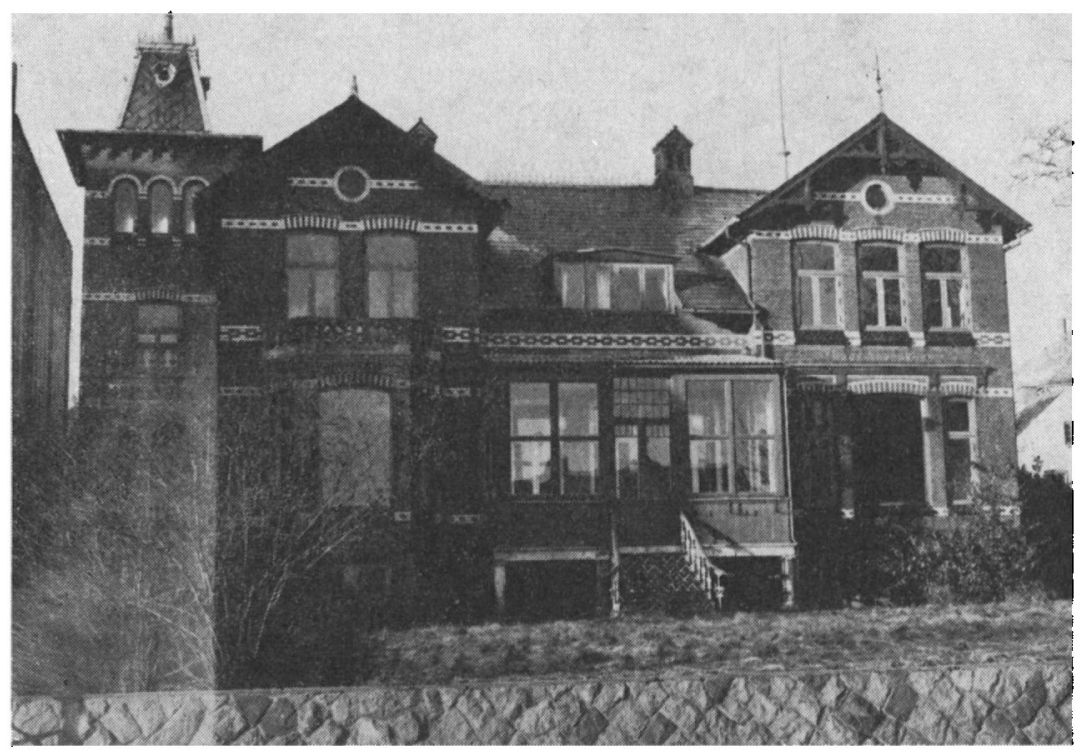

Haderslevvej 3, opfart 1901 af Peter Callesen d. yngre for kaptajn Scbütt.

små falstagsten som f. eks. på Statsskolens tag. Og endelig gik man i murbehandlingen over til pudset mur med enten sydtysk bindingsværk eller røde murbånd, inspireret af sygehuset og amtsbanegården.

Gode eksempler på den nye stilopfattelse i Langschwagers huse er Jørgensgaard 3-5 (1904-06) og 29 (1905), Frydendal 4 (1902), Karpedam 3 (1903) og Forstalle 27 (1908).

Højt over Løgumklostervej troner Carl Iversens Villa Frida, Bjerggade 1 (1904), og endvidere har han bygget huse som Haderslevvej 21 (1902), Klinkbjerg 26 (1908) og Lindsnakkevej 11 (1904). J. D. Sørensen byggede huse som Jørgensgård 33-35 (1904-06) og Dambjerg 15 (1906) og Dethlefsen f. eks. Karpedam 8 (1908) og Jørgensgård $17 \mathrm{og} 31$ (1906-07). Endelig havde byen nu fået ansat en stadsbygmester Clausen, der bl. a. byggede arbejderboliger ved Lavgade og et hus til sig selv, Forstalle 25 (1906).

Alle de ovennævnte bygmestre/arkitekter byggede videre til 1914, ikke mindst $i$ de nordlige villakvarterer. Men også $i$ den indre by kom de nye stiludtryk til udfoldelse. Ramsherred 8 byggedes allerede 1900 af en arkitekt Jürgensen fra Haderslev og er, ligesom f. eks. 
det lille hus nr. 17 særdeles inspireret af det officielle byggeri. Et hus som Nørreport 14 (1907 af Iversen) er usædvanlig pyntet, men knytter sig mere til den næste periodes jugendstil.

Enkelte bygninger falder helt uden for mønstret, f. eks. Storegade 1 (facaden 1905) som Ottomar Langschwager ombyggede for Schleswig-Holsteinische Bank. Her fik huset en klassisk og storslået søjlefront. Det er et eksempel på, hvorledes særlige byggeopgaver i kraft af et specielt indhold kan kræve et specielt stiludtryk, en bank er noget helt andet end et privathus.

Det er nok dette ti-års byggeri, 1900-10, der for eftertiden kom til at stå som mest tyskpræget. Og det er uden for al tvivl, at det officielle byggeri, ikke mindst Jablonowskis, absolut var ment som en manifestation af det nye kejserriges selvfølelse. Men bygmestrene tog det til sig som endnu en ny mode uden særligt nationalt indhold, og de formåede $i$ mange af de store villaer og huse at skabe noget, der var præget af både godt håndværk og arkitektonisk fantasi.

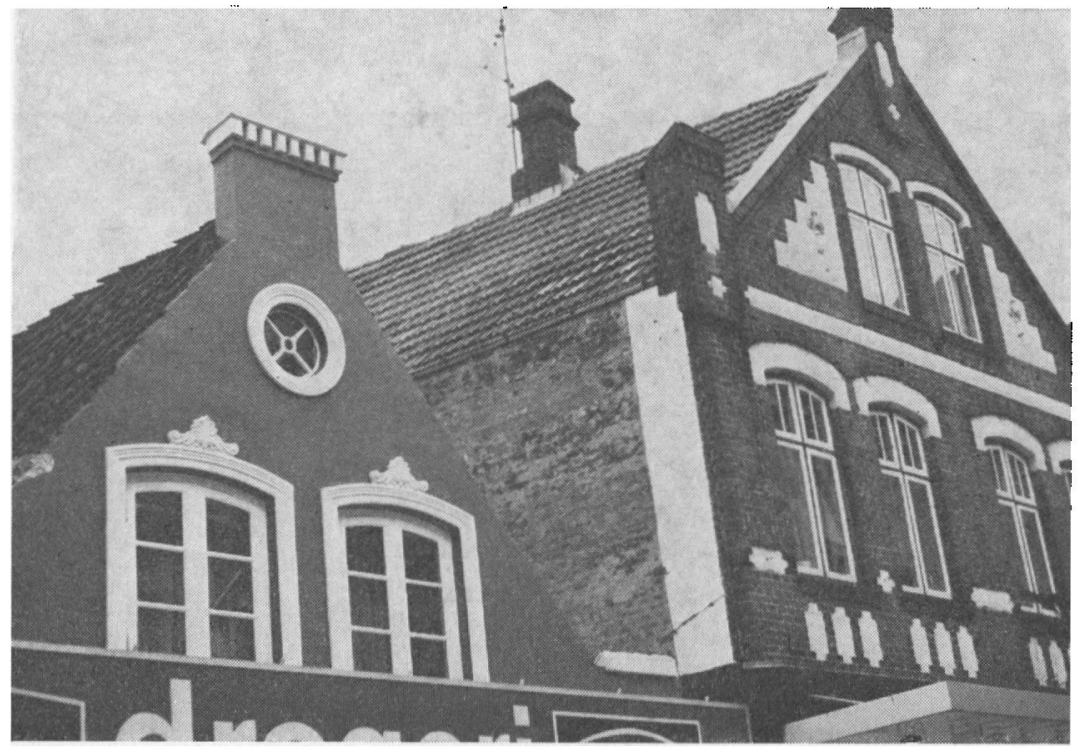

Ramsherred 15 og 17. Nr. 15 med gavl fra 1889, og nr. 17 bygget 1906 af $D$. Dethlefsen $i$ den af det officielle byggeri pavirkede stil, der slog igennem efter 1900. 


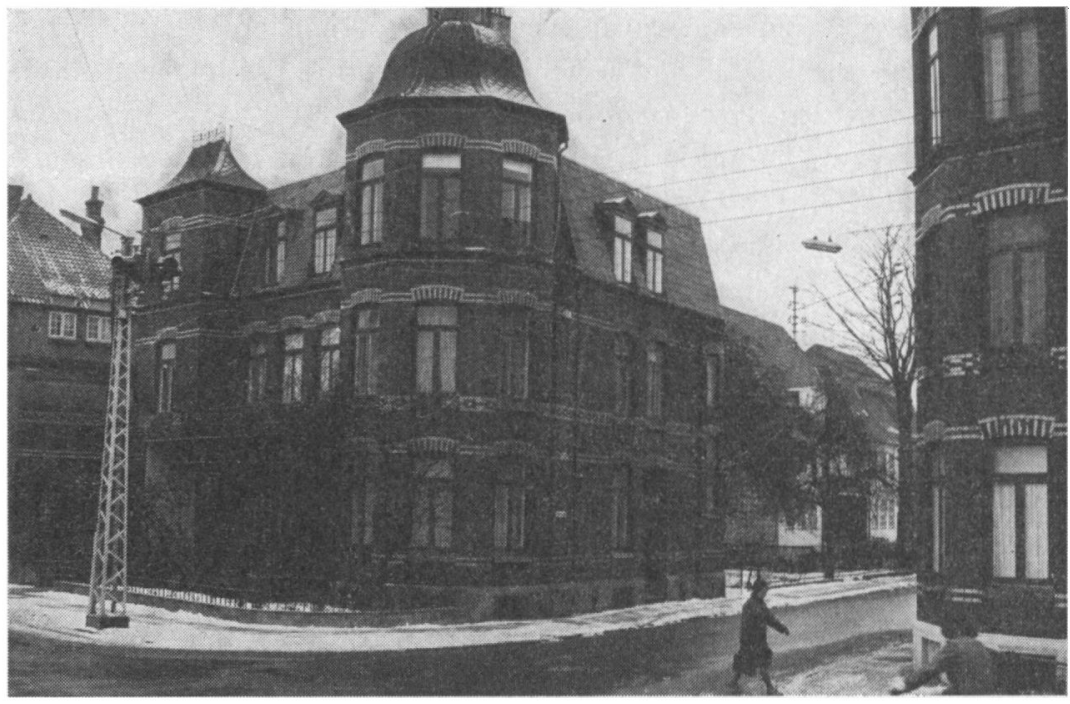

Hornet af Forstallé-Callesensgade, bygget 1898 og 1901 af og for Peter Callesen.

\section{Jugendstil og lokalstil}

I detailler som vinduer og døre, tit med glasmalerier, havde den nye stil, jugendstilen, allerede vist sig omkring 1900. I selve husene kommer der henimod 1910 en tendens til at forlade de historiske stiludformninger til fordel for et ønske om især originalitet, om en mere enkel og fri stil. Denne tyske jugendstil, der er så rigt repræsenteret f. eks. i Haderslev, for ikke at tale om Flensborg, kom ikke til at præge Åbenrå så meget.

I den gamle bydel er f. eks. Slotsgade 34 (1903) og Storegade 20 (1905 for skomager Boysen), begge af arkitekt Wehner, gode eksempler. Og forst på Forstallé ligger der dog to gode repræsentanter i nr. 7 (bygget 1906 af O. Langschwager) og nr. 9 (1910 af Robert $\mathrm{H}$. Luppi). Og inde i byen, Lille Pottergade 3, ligger et lille hus, der i 1904 af J. D. Sørensen fik en ualmindelig elegant facade. Ikke blot er dekorationerne særdeles originale; men husets udformning passer godt til gadebilledet. Det samme kan nxppe siges om alle de huse, der mellem 1890 og 1905 blev bygget i de gamle gader. Men nu begyndte man altså at få sans for miljøet. 
I det hele taget blev reaktionen mod den foregående periode kraftigere og kraftigere. Dette gav sig såvel $\mathrm{i}$ Tyskland som $\mathrm{i}$ resten af Nordeuropa udslag $\mathrm{i}$ et ønske om at bruge den lokale håndværksmassige og folkelig-anonyme byggeskik fra før 1800. I Danmark ser vi Foreningen for Bedre Byggeskik opstå, i England Arts and Craftsbevægelsen, og i Tyskland udgaves der bl. a. propagandabøger for den enkle Mecklenburg'ske lokalrokoko, der i en årrække før 1914 blev næsten national. Vi ser da også i Åbenrå eksempler på denne ikke-sønderjyske lokalstil, især i nogle villaer i Callesensgadekvarteret fra 1919-21; men det blev dog forskellige udgaver af gammel sønderjysk stil, der gik af med sejren. Ingwert Callesen brugte således helt lokale motiver i udlejningsejendommene Møllegade 13-15 (1907-08) og Tværgade 1. Det var egentlig den gamle postgård i Søndergade "oversat « til røde mursten. Også huse som Forstallé 29 (1909 af J. D. Sørensen) og Karpedam 4 (1912) 12 og 14 (1913 af P. Viereck) er tydeligt lokalt inspireret. Og selv om tiden også kunne bygge prangende som i Nørreport 12 (1907), kan man dog også være glad for adskillige småhuse som f. eks. Vægterpladsen 4 (1914), Slotsgade 20 (facaden 1913) og 7 (1913), der evner at indordne sig i et gammelt gadebillede.

Henimod 1914 bliver husenes udformning mere og mere bevidst lokalt inspireret, og dermed også mere og mere lig den stil, der herskede i Danmark på dette tidspunkt, ikke mindst påvirket af de opmålinger af gammel vestslesvigsk byggeskik, der var udkommet omkring 1900. Hovedmændene $\mathrm{i}$ denne udvikling var den nye arkitekt og bygmester Jep Fink, som skulle komme til at præge byggeriet i byen efter 1920 . Han startede ganske vist med at bygge $i$ den stadig mest tyskinspirerede jugendstil; men han tog hurtigt sine forbilleder nord for grænsen. Inden 1914 har han f. eks. bygget Storegade 7 (1909), Jørgensgård 21 og 23 (1909-12) og Karpedam 5 (1909).

Også de ældre arkitekter som Wehner, Dethlefsen, O. Langschwager og Iversen tog hurtigt de nye tider til sig. De to sidste byggede dog meget lidt efter 1910. - Ingwert og den yngste Peter Callesen havde i højere grad deres udgangspunkt i den nærmeste Åbenrå'ske og sønderjyske tradition. Dette ses tydeligt $f$. eks. i huse som Lavgade 24-26 og en række villaer på nordsiden af Jørgensgård, allesammen bygget $\mathrm{i}$ årene $1910-12$.

Der er nok ingen tvivl om, at især Jep Fink lagde et nationalt ind- 
hold i den stil, han fulgte. Men man skal alligevel være forsigtig med at slutte for meget deraf. Thi den stiludvikling, der skete, løb helt parallelt i Danmark og Tyskland, og resultaterne kom i Nordtyskland og Danmark til at ligge tæt op ad hinanden. Vi ser det $i$ det sidste tyske officielle byggeri før 1914, såsom Præparandanstalten $\mathrm{i}$ Callesensgade 26 fra 1914 og endvidere bankbygninger som den nuværende Sparekasse (1910) og Handelsbank (1915), som absolut ikke kan mistænkes for at have skullet understrege danske sympatier.

\section{Tysk og dansk $i$ byggeriet}

Vi må altså konkludere, at valget af en bygnings ydre udformning ikke mellem 1864 og 1920 har været ladet med noget synderligt nationalt indhold. Udtrykket tysk om byggeriet før 1914 som helhed må derfor være opfundet efter 1920. Det er nok ikke mindst arkitekter som Fink og andre efter ham, der har brugt udtrykket som et ekstra argument $\mathrm{i}$ den almindelige reaktion mod århundredskiftets stil. Et er i hvert fald sikkert: bygmestrene selv folte, at de blot rettede sig efter tidens mode, og de anså den måske for mere generel, end vi bagefter kan konstatere, at den var. Alligevel kan man ikke sige, at det nationale ikke spillede en rolle, $i$ hvert fald efter ca. 1890.2 Men det var blot på en anden måde, nemlig ved valget af bygmester. Langschwager var kendt som tysksindet, Callesen som dansksindet, mens andre som $\mathrm{f}$. eks. Carl Iversen måske var mere neutrale. Deres huse var imidlertid identiske, når de blev bygget samtidigt.

$\mathrm{Nu}$ kommer vi til spørgsmålet, om hvorvidt vi alligevel kan tillade os at betegne periodens arkitektur som »tysk «præget? Og her var det jo tydeligt, at Sønderjylland efter 1864 til forskel fra Danmark fortsatte sin tilknytning til det nordtyske område. Herom bærer såvel nygotikken fra 1870'erne som tyrolerstil og jugendstil fra 1890'erne og begyndelsen af 1900-tallet tydelige vidnesbyrd. Dog må man huske, at den fælleseuropæiske bygningskultur i slutningen af 1800tallet gav en så stor spredning af de fleste enkeltelementer, at man også i det "gamle land " vil kunne finde paralleller til de fleste af periodens Ảbenrå'ske huse. Men her var vi behandlet helhedsindtrykket, og det var et andet. 


\section{Stil og mode}

Til sidst ville det være relevant at diskutere, hvordan moder, stilarter og stiltræk egentlig bredte sig blandt bygmestre på den tid. Skønt J.H. Callesen på et tidspunkt havde ca. 70 ansatte og O. Langschwager over 100, da han havde flest arbejdere, optrådte der først et stykke efter 1900 overhovedet en, der kaldte sig arkitekt i byen. Der har antagelig været udsendt tidsskrifter og håndbøger $\mathrm{i}$ »Architektur«. Både Peter Callesen og Wilhelm Langschwager havde gået på Baugewerkschule i Tyskland, Callesen i Holzminden, og de havde rejst som svende $i$ Tyskland. Langschwager havde $f$. eks. hentet inspirationen til Landlyst ved Skinderbro i Rhinegnene. Her havde de vel fået personlige kontakter, som de kunne vedligeholde forbindelsen med sidenhen; men derom ved jeg ikke meget.

Mod disse internationale påvirkninger kunne så stå bygherrens mere lokalprægede ønsker. I 1850'erne kan han have sagt: "Det skal ligne Rådhuset! « Og senere er det påfaldende, at byens store huse tit kan genkendes to og to, som f. eks. Ramsherred 51 og Søndergade 7, der gaber over et åremål på 16-17 år.

Jeg har her dels forsøgt at give en oversigt over byggeriet i Åbenrå fra ca. 1840-1914. Her har jeg prøvet at satte byggeriets udformning ind $\mathrm{i}$ en større helhed ved bl. a. at vise, hvorfra inspirationerne til de vekslende stilformer kom, og hvorledes de udfoldede sig under lokale forhold.

Og ikke mindst håber jeg at have medvirket til at give et mere nuanceret billede af periodens byggeri. Det er mit håb, at Åbenrås beboere ikke blot får en endnu større forståelse for de huse, der omgiver dem, men også ser, at enhver periode har bidraget med noget værdifuldt til vore byers hele profil. Noget der, måske uden at vi egentlig ved af det, bidrager til det særpræg, vi kan lide ved den by, vi bor $i$.

Og dels har jeg forsøgt at vise, hvorledes en bys byggeri afspejler den sociale struktur; hvorledes byggeriet indicerer og kan forklares ved forskellige forandringer $\mathrm{i}$ erhverv, økonomi, samfærdsel, administration, befolkningens sammensætning, flytninger, kontaktmønstre etc., alt efter hvor, hvordan og for hvem, der bygges.

Endelig må man også huske, at et hus, både fra bygherrens og bygmesterens side, har en status, der er afhængig af kulturelle vurderin- 
ger. En facade kan f. eks. give udtryk for rigdom og kreditværdighed, klassisk dannelse og væren med på noderne. Storborgeren kan $f$. eks. prøve at leve op til rådhuset, byens bygning nummer ét, mens rentier'en vil skabe sig et lille landsted. Og hjemmet kan ikke blot afspejle husstandens størrelse og funktioner, men også større og mindre krav til repræsentation, gæsteri osv. Og så er jeg slet ikke her kommet ind på så vigtige områder som boligindretning, ruminddeling, arbejdspladsens indretning (kontor, butik, værksted, udhuse), og f. eks. den enkelte husstands økonomi set i forhold til faktorer som husleje, leje og selveje af huset osv. Ja, egentlig er byggeriet jo et produkt af en tids hele kultur, noget som man kan bruge år på bare at sætte sig nogenlunde ind $i$, men som var dagligdag for - $i$ denne artikel - vore bedste- og oldeforældre.

\section{Utrykte kilder:}

Landsarkivet for de sønderjyske landsdele, Ảbenrå:

Topografica. Ảbenrå by. Peter Callesen: Taxation zur Brandt Casse der Stadt Apenrade, 3. okt. 1825, med bemærkninger af J. H. Callesen fra ca. 1905.

Ảbenrå landinspektorat: 1898-1907. Mietpreissammlungen. 1892. Gebäudebeschreibungen.

Ábenrå byarkiv: 1873-89. Sager vedr. nybygninger og byggepolitik. 187199. Brandtaksationsprotokoller.

Abenrå rådhus:

Forskellige byggeudvalgssager.

Byggesager.

Sager vedr. erhvervsvirksomheder og arbejdere.

1885-1910. Folketællinger for Ảbenrå by.

\section{Litteratur ( i udvalg):}

Johan Hvidtfeldt og Peter Kr. Iversen (red.): Ảbenrå Bys Historie, bd. II, 1721-1864, 1967.

G. Japsen: Den nationale udvikling i Ȧbenrå 1800-1850, 1961.

Kn. Millech: Danske arkitekturstrømninger 1850-1950, 1951.

Gregor Paulsson (red.): Svensk Stad 1-2, Stockholm 1950. 


\section{NOTER}

1. Iflg. en familietradition skulle tårnene være inspireret af det danske Fredensborg Slot.

2. Kort efter 1880 bad den tyske Schützenverein bygmester Langschwager om at bygge Skyttegården. Hvis man allerede dengang har valgt bygmester efter nationalitet, kan man altså tilbage til 1875-80 bestemme en del huse ud fra kendskabet til bygherrens sindelag. Det gxlder f. eks. Ramsherred 37, der byggedes 1880 for købmand Voetmann, hvis evt. tilhørsforhold jeg ikke kender. Muligt er det også, at P. Callesens to mistede byggerier i 1900 skyldes dette forhold.

Forfatteren vil gerne takke alle, der har bistået med oplysninger og med at finde frem til de relevante arkivalier, nemlig landsarkivets personale, fhv. kommunaldirektør J. Christensen, fuldmægtig Holger Jacobsen og arkitekterne på byggesagskontoret i Åbenrå. Endelig er der blevet givet nyttige oplysninger fra Callesens og Langschwagers efterkommere.

Artiklens fotografier er alle på nær ét taget af forfatteren. 